\title{
Social Consciousness and The Mind
}

\author{
Charles Pidgeon* \\ Neuroscience Sensory Unit, which I founded and operate, USA
}

*Corresponding author: Charles Pidgeon, Neuroscience Sensory Unit, which I founded and operate, USA,

Email: neurosensoryunit@gmail.com

\section{Mini Review}

Today, the COVID-19 problem has raised social consequences more than any time in modern society. Few, if any believe that God (god) will solve the global population of the current COVID-19 pandemic; instead they believe that the scientists will be the global hero's'. This idea has recently been epitomized from a comparison of how Seattle handle the COVID-19 outbreak vs New York City (NYC). Seattle gave control to the scientists whereas NYC did not. Consequently, Seattle had a 6 times reduced infection rate compared to NYC during the initial months of the outbreak. At no other time in contemporary society has global social consciousness been as profoundly obvious [1].

Scientists, using their minds, have typically played a background role in political decisions and America has suffered because of this. Too many people in the general population don't understand how scientists contribute. The COVID-19 pandemic increased the social status of scientists because it is from minds of scientists that will solve the problem. Embodied Cognition [2] defines the Mind as being the dynamic (50 millisecond rates) interactions between the brain, body, and environment. Scientists must use their (i) brain to think of solutions to the Pandemic and design experiments to solve the problem, (ii) body to carry out the experiments, and (iii) their environment also to carry out experiments. Hence it is the Minds of many different people that will solve all the problems needed to survive the Pandemic with scientific minds solving the discovery aspects needed to fight the virus. The obvious conclusions is that the hopes of people are rooted in the collective minds of other people. Currently, the Mind was posited by Kiverstein J and Miller $\mathrm{M}$ [2] as follows:

"...We will no longer be able to claim that the brain is the organ of the mind. Instead we will need to think about mind and the cognitive processes that make up the mind at the level of the whole brain-body-environment system."
However, during historical times, Religions, and more specifically belief in God, was the unifying social fabric that gave people hope in times of war, pandemics, etc. To continue or maintain social consciousness, it is useful to compare origin of each societie's hope during historical times with contemporary society. This can be achieved by comparing the word God to Mind in some of the main beliefs in society in both a religious and financial context. With regard to religion as a source of hope, the original Serenity Prayer (SP) [3] epitomizes belief in god, yet contained significant social wisdom:

God, grant me the Serenity to accept the things I cannot change, change the things I can, and the wisdom to know the difference.

The SP attributes God to a person achieving peace and serenity. In other words, people did/do not have to rely on themselves for accepting things they cannot change and changing the things they can. Noteworthy, there is universal social wisdom (sw) following the word God in the SP. However, from a human perspective the sw advice can only be implemented when people use their minds. Consequently, I suggest substituting the word Mind for God. This substitution humanizes the SP and I have denoted this modification as the hSW (human social wisdom statement), which is not a prayer. It is written as

Mind, grant me the Serenity to accept the things I cannot change, change the things I can, and the wisdom to know the difference.

The original SP was written in 1934 by Reinhold Niebuhr, approximately 85 years ago, and Niebuhr was a Religious scholar [3]. However, over the last several decades a scientific understanding of the Mind has exploded from many perspectives which include neural processing of creativity, decision making, emotion, attention, sensory system cortical processing, etc. It is timely for the global community to consider and think about the contemporary 
significance by contrasting the SP to the hSW. Many 12 step addiction recovery programs, particularly Alcoholics Anonymous, utilize the SP and this comparison will provoke discussions that lead to an increased understanding of social consciousness with regard to the role of the mind in human behavior.

Using the word God creates a prayer, i.e., a deity, who can give Serenity, whereas using the word Mind(s) means that people are to take responsibility for their own Serenity. In support of hSW being more contemporary, it has recently been published [4]. Fred Previc's opinion of the contrast between SP and hSW is interesting:

"God' may be the producer of the universe but 'god' is a product of the human mind and its dopamine." "god" would exist even if "God" doesn't."

which posits that the concept of any god existing is a direct consequence of human minds, i.e., human minds created all god concepts. This resurrects and elucidates the age old Philosophical and Theological debate regarding God came first and created human's vs Humans came first and created different gods, using their minds.

More salient to improving social consciousness are thought provoking concepts that form a stronger link between people who are commercial globalizers (goods and services) with social globalizers (pursuing the qualia of human life). A common element between these groups is purchasing goods and services using cash or credit cards. It is suggested to modify both American currency and credit cards to stimulate conversations between commercial and social globalizers. Regarding American currency

“... a Joint Resolution by the $84^{\text {th }}$ Congress (P.L. 84-140) and approved by President Dwight Eisenhower on July 30, 1956, requires that "In God We Trust" appear on American currency."

Wikipedia, https://en.wikipedia.org/wiki/In_God_We_Trust
Note that the capitalized form of "In God We Trust" is used today and in1956 the religious situation of America justified using God. Today, it is more salient to modify this phrase to "In Minds We Trust" because it is much more contemporary by emphasizing that all goods and services, infrastructure and political parties, etc., were created from the minds of people. Suggesting this modification provokes conversation among virtual every American social group. An example of a $\$ 100$ bill follows

Credit cards are used instead of cash for most purchases in America. There are trillions of credit card transactions per year in America. For this reason it is suggested that a Social Credit card be created with the following cognitive anchors: (i) In Minds We Trust, (ii) an image of a human head, (iii) an American flag deformed to represent a brain and (iv) the phrase We the People as written in the United States Constitution. An example of such a credit card is shown in Figure 2.

Figure 1 Recognizing that the world was built from people using their Minds, facilitates social reform from being primarily guided by money considerations, to at least some emphasis that money, and what it is used for, is a creation from and for society by people using their Minds. Social guidance may be more socially significant today, than any other point in history. A two-penny tax on each credit card transaction could generate than \$1B annually for social purposes, perhaps health care (for instance the poor). Why Not? The people paying the credit card fee would be the people getting health care. Obviously, the funds could be used for any social purpose, but should be used to impact the greatest number of people. A better use of the money generated may be to use it as a fund for all Politicians raising money for election purposes. In other words, this could minimize, or perhaps eliminate, the need for big donors who have significant control of the Congress and Senate in America. If more money is needed for political campaigns than merely increase the tax to 3 peenies which would generate multiple billions of dollars annually.

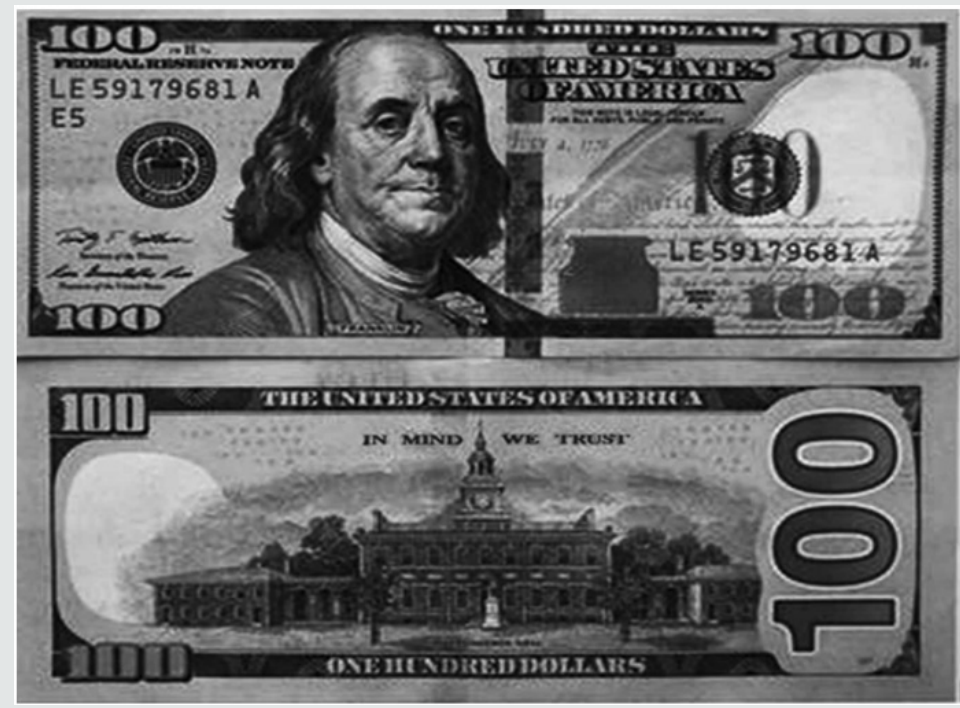

Figure 1: An example of a $\$ 100$ bill follows. 
Probably more provocative in stimulating social discussions and enhancing Social Consciousness are Mind Money(C) Credit Cards (Figure 2) instead of Mind Money® currency (Figure 1). Credit cards are used much more frequently in paying for goods and services than cash. We suggest creating these items is particularly timely given the current elevated state of Social Consciousness. A key question is what the role of the deity gods in helping people with regard to providing hope for the future. From the above discussion I believe that the Minds of people will have a more significant role in social consciousness than gods.

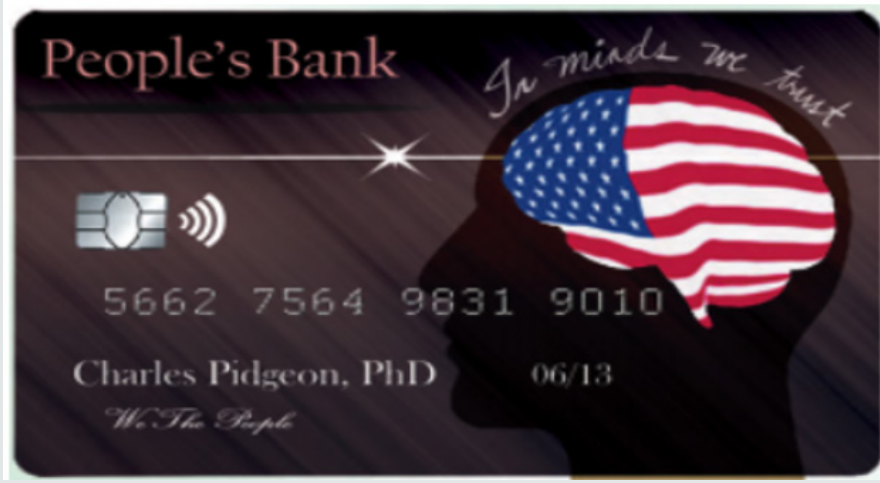

Figure 2.

\section{References}

1. Duhiggm C (2020) Seattle's Leaders Ley Scientists Take the Lead. New York's Did Not, The New Yorker. Annals of Epidemiology May 4, 2020 Issue.

2. Kiverstein, J and Miller M (2015) The embodied brain: towards a radical embodied cognitive neuroscience. Front Hum Neurosci May 06.
3. Kirsch A (2015) The Ironic Wisdom of Reinhold Niebuhr. The New York Review of Books.

4. Pidgeon C (2020) Social Conscious Pedagogy. Mainspring Books Publisher, in press. ISBN book number 978-1947352-90-2, in press. (c) This work is licensed under Creative

To Submit Your Article Click Here:

Submit Article

DOI: 10.32474/RRHOAJ.2020.05.000216

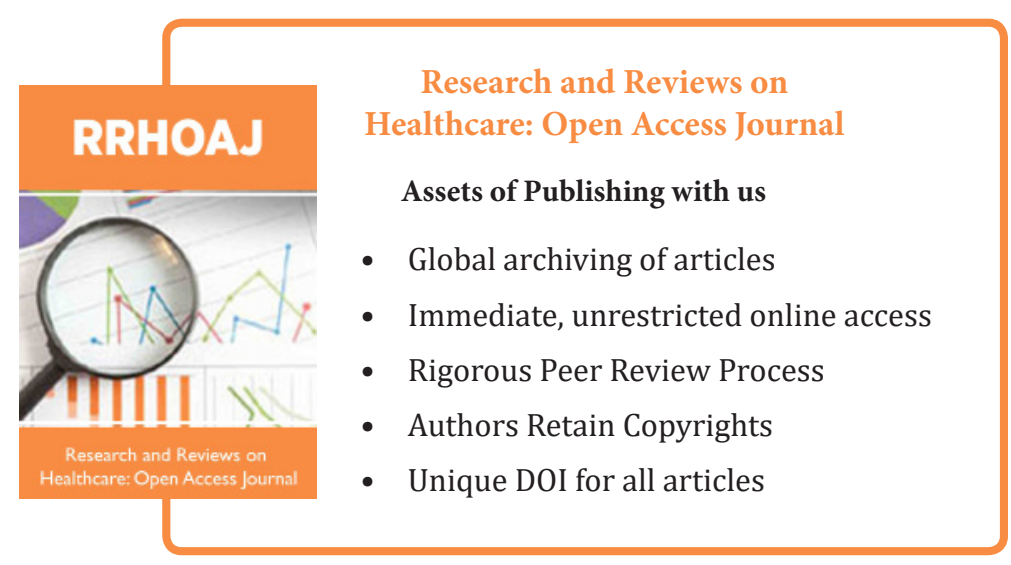

